\title{
Penguatan Nilai-Nilai Wawasan Kebangsaan bagi Calon Jamaah Haji
}

\author{
Briliyan Ernawati, Saifudin, Mohammad Tajuddin Arafat \\ Universitas Islam Negeri Walisongo Semarang \\ Email : berilian_ernawati@walisongo.ac.id
}

\begin{abstract}
The enthusiasm of Indonesian society to fulfill the worship of hajj is the reason for the long queue of quota of pilgrimage. Therefore, strong commitment is needed for Hajj pilgrims in improving services to pilgrims Hajj. One form of service is the assistance in the form of guidance of pilgrims held by Hajj pilgrims in their respective areas. Hajj pilgrimage during this only focus on the hajj manasik only. In the history of Islam in Indonesia shows that Haj is one of the effective path in the process of disseminating knowledge and understanding of Islam to Indonesia. The method used in this activity is by using the Focus Group Discussion (FGD) method. The result of this activity is that pilgrims are in need of this kind of provision to fortify them from radical Islamic ideology especially those that lead to the movement to establish an Islamic caliphate. All elements must play an active role in counteracting this movement that is by strengthening the values of national insight for prospective pilgrims jama'ah. Hajj Guidance Group (KBIH) should be able to play a role in overcoming this problem.
\end{abstract}

Abstrak: Antusias memasyarakat Indonesia untuk menunaikan ibadah hajimenjadi alasan panjangnya antrean kuota ibadah haji. Oleh karena itu, diperlukan komitmen yang kuat bagi penyelenggara haji dalam meningkatkan pelayanan kepada jamaah haji. Salah satu bentuk pelayanan tersebut adalah pendampingan dalam bentuk bimbingan manasik haji yang diselenggarkan oleh penyelenggara haji di daerah masing-masing. Pendampingan jamaah haji selama ini hanya fokus terhadap manasik haji saja. Dalam catatan sejarah Islam di Indonesia menunjukkan bahwa haji merupakan salah satu jalur yang efektif dalam proses penyebaran keilmuan dan paham Islam ke Indonesia.Metode yang digunakan dalam kegiatan ini adalah dengan menggunakan metode Focus Group Discussion (FGD). Hasil dari kegiatan ini adalah bahwa calon jamaah haji sangat memerlukan pembekalan semacam ini untuk membentengi mereka dari ideologi islam radikal lebih-lebih yang mengarah pada gerakan mendirikan khilafah islamiyah. Semua elemen harus berperan aktif dalam menangkal gerakan ini yaitu dengan menguatkan nilai-nilai wawasan kebangsaan bagi calon jama'ah haji. Kelompok Bimbingan Ibadah Haji (KBIH) harus mampu berperan dalam mengatasi masalah ini.

Kata Kunci: jamaah haji, penguatan, wawasan kebangsaan 


\section{PENDAHULUAN}

Jumlah pendaftar jamaah haji di Indonesia dari tahun ke tahun terus bertambah secara signifikan. Data masa tunggu (waiting list) jama'ah haji Provinsi Jawa Tengah sesuai Sistem Informasi dan Komputerisasi Haji Terpadu (SISKOHAT) sampai saat ini mencapai hampir 546.614 jamaah dengan prediksi keberangkatan hingga tahun 2040. Banyaknya calon jama'ah haji menuntut komitmen yang kuat bagi penyelenggara haji dalam meningkatkan pelayanannya. Salah satu bentuk pelayanan tersebut adalah pendampingan dalam bentuk bimbingan manasik haji yang diselenggarkan oleh penyelenggara haji di daerah masing-masing.

Menyikapi persoalan kekinian yaitu maraknya penyebaran ideologi islam radikal, pendampingan bagi calon jamaah haji tidak cukup hanya fokus pada manasik haji tetapi juga pendampingan pada faktor lain. Hal ini mengingat bahwa haji merupakan aktifitas keagamaan yang memiliki beragam aspek, baik ibadah, ekonomi, sosial, politik, budaya, transformasi keilmuan, dan penyebaran ideologi. Aspek yang terakhir inilah yang menjadi fokus perhatian karena dalam catatan sejarah Islam di Indonesia menunjukkan bahwa haji merupakan salah satu jalur yang efektif dalam proses penyebaran keilmuan dan ideologi Islam ke Indonesia.

Menurut Azyumardi Azra (1994) menyatakan bahwa Tanah Suci sejak lama memang telah menjadi basis keilmuan Islam, serta menjadi simpul bagi penyebaran beragam ajaran Islam, baik aqidah, syariah, maupun tasawuf. Oleh karena itu, bagi mereka yang sedang beribadah haji tidak hanya menjalankan ritual ibadah saja, melainkan pula belajar dan menerima pengetahuan dari berbagai halaqah ulama yang ada di Tanah Suci. Tradisi keilmuan yang berada di Tanah Suci mengalami pergeseran ketika gerakan Wahabisme mendominasi halaqah-halaqah di dua masjid suci tersebut.

Wahabisme, aliran pemikiran dan gerakan Islam yang pertamakali muncul di jazirah Arab pada abad kedelapan belas, adalah paham keagamaan yang dipelopori oleh seorang ulama dari Nejed yang bernama Muhamamd bin Abdul Wahab (Hamid Algar, 2011:7). Salah satu ajaran yang mencolok adalah usaha purifikasi ajaran-ajaran Islam dari beragam bid'ah, khurafat dan tahayyul.Purifikasi berarti pembersihan, pemurnian, dan penyucian. Gerakan purifikasi yang muncul dalam Islam biasanya disebut dengan tajdid atau islah. Islah artinya ialah gerakan yang berusaha untuk memperbaiki kondisi umat yang lemah akibat tradisi, praktik, dan kepercayaan yang salah. Dari sini islah digunakan untuk menyebut gerakan purifikasi (Issa J. Boulatta, 2001: 19-20). 
Istilah lain yang digunakan untuk menyebut gerakan semacam itu ialah gerakan salaf yang secara harfiah berarti "lampau". Maknanya ialah suatu gerakan yang mencoba mengembalikan kondisi Islam seperti pada masa generasi salaf (lampau) di mana Islam masih murni dan belum bercampur dengan konsepkonsep teologi asing. Hal ini didasarkan pada pengamatan historis bahwa timbulnya berbagai aliran pemikiran pasca generasi salaf, khususnya teologi dan falsafah, menyebabkan kehancuran Islam. Untuk menghindari kehancuran itu, umat harus kembali ke masa salaf, karena Nabi mengatakan, "Sebaik-baik kurun ialah di mana aku hidup, setelah itu kurun sesudahnya, dan sesudahnya".

Gerakan purifikasi dalam sejarah pemikiran dan gerakan Islam telah memberikan sumbangan signifikan baik dalam proses reorientasi paham keagamaan maupun dinamisasi Islam. Sebab biasanya gerakan purifikasi mengandung makna usaha agar agama menjadi fungsional dalam sebuah masyarakat yang mengalami kebekuan sebagai akibat jangka panjang dari sikap akomodasi kultural dan ketimpangan politik.

Istilah purifikasi (purification) berarti pemurnian, atau tandhif dalam bahasa Arab. Istilah tandhif tidak populer jika yang dimaksud adalah gerakan pemurnian Islam. Gerakan pemurnian lebih dikenal dengan istilah al-ashalah atau ishlah yang berarti gerakan yang berusaha untuk memperbaiki kondisi umat yang lemah akibat penyimpangan pengamalan Islam.

Tokoh yang berperan besar dalam gerakan purifikasi Islam adalah Muhammad bin Abdul Wahhab. Pemikiran dan gerakannya mempengaruhi banyak tokoh muslim pada masa modern. Gerakan mereka lazim disebut sebagai Wahhabisme yang didasarkan pada pandangan bahwa aqidah umat Islam telah banyak bercampur dengan syirik, bid'ah, khurafat dan tasawuf sehingga mereka menjadi jauh dari Islam yang benar.

Gerakan ini memiliki gaung yang besar karena dukungan politis dari pemerintah Saudi. Gerakan purifikasi Islam selanjutnya menyebar ke berbagai kawasan muslim di dunia dengan bermacam orientasi ideologis. Gerakan ini di dukung penuh oleh Kerajaan Arab Saudi sehingga memiliki jaringan yang kuat di Arab Saudi, terutama di kawasan Tanah Suci. Mereka memanfaatkan musim haji sebagai media dakwah dan penyebaran paham keagamaan yang mereka yakini. Selain itu, gerakan ini, oleh sebagian pakar, juga dikenal fundamentalis dan radikal dalam aktifitas dakwahnya. Sehingga, terkadang menimbulkan gesekan dan konflik dengan golongan yang lainnya.

Pada pertengahan abad ke-20 wacana dan gerakan purifikasi semakin menguat bersamaan dengan kekalutan umat Islam dalam menghadapi penetrasi budaya Barat, atas nama modernitas. Umat Islam berusaha mempertemukan apa 
yang disebut dengan al-ashalah wa al-mu'asyarah. Menurut Boullata, dilema itu membelah umat menjadi tiga kelompok. Pertama, mereka yang menganggap ajaran Islam dan warisan Islam harus dirumuskan dan diubah kembali secara menyeluruh sehingga kompatibel dengan modernitas. Kedua, kelompok yang mereformasi sebagian tradisi Islam sesuai dengan keperluan modernitas. Ketiga, kelompok yang meyakini tradisi Islam merupakan satu-satunya elemen untuk membenahi kemunduran umat Islam. Mereka tidak ingin mentransformasi dan mereformasi tradisi Islam tetapi lebih ingin menyesuaikan dengan apa yang dianggapnya sebagai sumber-sumber Islam otentik.

Kegiatan ini dilaksanakan dengan menggunakan dua model pendekatan yaitu pertama focus group discussion (FGD). Sample yang diambil dari kegiatan ini adalah para calon jamaah haji yang ada di berbagai Kelompok Ibadah Haji Indonesia $(\mathrm{KBIH})$ seperti $\mathrm{KBIH}$ As Shodiqiyah dan KBIH Nahdlatul Ulama Kota Semarang. Kedua KBIH ini yang dijadikan sampel karena kedua $\mathrm{KBIH}$ tersebut yang tergolong besar di Kota Semarang. Tempat pengumpulan data dilaksanakan di 4 (empat) tempat yaitu di Kelompok Bimbingan Ibadah Haji As Shodiqiyyah Kaligawe Semarang, Kelompok Bimbingan Ibadah Haji Nahdlatul Ulama Kota Semarang, Masjid Wonolopo Mijen Semarang, dan Aula Kantor Kecamatan Tugu Semarang. Rentang waktu pelaksanaannya adalah mulai Rabu, 28 Juni 2017 sampai dengan Rabu, 2 Agustus 2017.

Analisis data ini menggunakan teknik analisis data kualitatif. Analisis data kualitatif adalah proses analisis kualitatif yang berdasarkan pada hubungan antara variabel-variabel yang sedang dikaji. Teknik analisis data ini dengan menggunakan teknik penyajian data yaitu dengan menyusun beberapa informasi yang berhasil dihimpun dan dikumpulkan. Dari informasi yang sudah dihimpun dan dikumpulkan tersebut memungkinkan penulis untuk menarik kesimpulan berdaarkan data tersebut. Bentuk penyajian data ini berupa teks naratif yang berbentuk catatan-catatan.

\section{SEMANGAT NASIONALISME BANGSA INDONESIA}

Nasionalisme kebangsaan akhir-akhir ini mulai pudar seiring dengan munculnya kelompok-kelompok baru yang membawa ideologi kekerasan. Ideologi ini mengangap dirinya sendiri paling benar dan menyalahkan kelompok lain, serta melakukan tindakan-tindakan intoleran. Bahkan dalam ranah tertentu melakukan gerakan politik yaitu ingin mengubah dasar Negara Pancasila dan bentuk Negara kesatuan republik Indonesia. Tentu, ini merupakan fenomena membahayakan dan tidak diinginkan.

Cita-cita nasionalisme yang tercantum dalam pembukaan UndangUndang Dasar (UUD) 1945 sampai saat ini belum terwujud sepenuhnya. 
Landasan nasionalisme yang menegaskan pada kesejahteraan dan keadilan rakyat seluruh Indonesia belum diperhatikan oleh penyelenggara negara. Akibatnya rakyat makin menderita dan timbul gejolak sosial di mana-mana. Itu disebabkan kesejahteraan rakyat belum merata. Kondisi ini sangat memprihatinkan dan memilukan bagi bangsa yang begitu besar dengan kekayaan alamnya yang melimpah ruah. Kondisi sosial kebangsaan yang ambruk disebabkan makin rendahnya kesadaran komponen bangsa ini akan ruh nasionalisme. Semangat nasionalisme di kalangan masyarakat Indonesia kini diragukan. Derasnya ideologi asing yang masuk ke Indonesia dianggap sebagai salah satu pemicunya. Saat ini banyak masyarakat yang terjebak dalam pemahaman-pemahaman agama secara ekstrem, keras dan intoleran, sehingga mereka lupa bahwa Indonesia adalah bangsa besar, bangsa sangat toleran dengan golongan manapun, kelompok apapun demi terciptanya kebersamaan dan terwujudnya cita-cita bangsa.

Sebagai contoh banyak organisasi-organisasi keagamaan yang cenderung melakukan kekerasan dibandingkan dengan dialog dalam mencari solusi. Kelompok tersebut sering melakukan tindakan anarkis, kekerasan, mengkafirkan, dan membid'abkan. Kelompok ini secara kuantitas sedikit tetapi gerakannya yang didukung dengan teknologi informasi yang kuat menjadikan seolah-olah kelompok ini banyak. Kondisi demikian sangat memprihatinkan. Untuk kembali menumbuhkan semangat nasionalisme di kalangan masyarakat Indonesia, terutama adalah calon jama'ah haji Jawa Tengah, diharapkan nilainilai Pancasila semakin dipahami, merenung dan melihat kembali sejarah dan nilai-nilai Pancasila.

\section{PENGARUH JAMAAH HAJI TERHADAP PEMIKIRAN ISLAM DI INDONESIA}

Penyebaran pemikiran Islam dari timur tengah (baca: Arab Saudi) ke Indonesia melalui banyak cara. Cara yang lazim digunakan adalah melalui pendidikan di mana negara tersebut memberikan beasiswa kepada pelajar-pelajar Indonesia untuk kuliah atau belajar di timur tengah khususnya Arab Saudi. Di samping itu dapat juga dilakukan dengan negara minyak tersebut memberikan bantuan untuk membangun pendidikan di Indonesia dengan syarat kurikulum yang dibuat berdasarkan konsep mereka. Selain yang sudah disebutkan tadi, ada cara lain yang mungkin kurang pantauan dari publik, yaitu penyebaran paham wahabi melalui jama'ah haji. 
Penyebaran paham wahabi melalui jamaah haji dapat dilacak melalui karya Yudha yang berjudul Pengaruh Haji terhadap Politik Islam di Indonesia (Tahun 1900 - 1945) (Yudha, 2015: 40 -45). Dalam tulisan tersebut menjelaskan bahwa ibadah haji merupakan salah satu peribadatan yang bisa dikatakan mencakup isi peribadatan yang lain dalam Islam. Seseorang yang telah melaksanakan ibadah haji, secara spiritual telah sempurna Islamnya. Islam memandang secara seimbang antara nilai materiil dan nilai spiritual. Seseorang yang telah sempurna amal ibadah Islamnya dengan berhaji akan sempurna pula amal usaha keduniannya. Ibadah haji mempunyai pengaruh besar dalam berbagai bidang seperti bidang politik, bidang ekonomi, dan bidang pendidikan. Bahkan di era penjajahan Belanda, haji sangat ditakuti sebagai bagian dari Islamophobia. Dikarenakan adanya pandangan seperti itu maka orang yang akan melaksanakan ibadah haji selalu dihalangi dengan jalan harus memperoleh izin terlebih dahulu dari penguasa Belanda (M. Shaleh Putuhena, 2007: 291).

Ada dua aspek penting mengenai para haji. Pertama, para haji dianggap sebagai orang suci, sehingga rakyat sederhana terlalu cepat berkesimpulan bahwa mereka mempunyai keistimewaan. Bagi pemerintah Belanda terkadang menganggap bahwa orang Islam yang menunaikan ibadah haji sebagai suatu "golongan pendeta". Secara sosial peranan mereka adalah menghabiskan waktu dengan sembahyang atau melakukan ritual-ritual lainnya. Kedua, adanya unsur politik, para haji memiliki pengaruh politik dan sering berperan sebagai pemimpin suatu gerakan untuk melawan penjajah.

Sebagian besar haji memang tidak terkena pengaruh fanatik di Mekah. Sejak awal mula kedatangannya di Indonesia, Snouck telah berusaha meyakinkan para pejabat kolonial bahwa mereka tidak perlu khawatir dengan pengaruh haji. Cara mengatasi masalah haji yaitu dengan menghambatnya secara halus dan tidak langsung yakni dengan mengalirkan semangat pribumi ke arah lain.

Pada tahun 1803, tiga orang ulama Minangkabau, Haji Miskin, Haji Sumanik, Haji Piabang kembali dari Mekah. Mereka menginginkan pembersihan praktik-praktik keagamaan yang masih sinkretik, sebagaimana yang pernah dilakukan oleh kaum Wahabi di Mekah. Mereka melihat bahwa kaum Wahabi berhasil menghapuskan kegiatan-kegiatan yang tidak sesuai Islam. Mereka membawa pulang pemikiran baru yang didapatkan di tanah suci dan menerapkan di daerahnya. Gerakan mereka kemudian dikenal dengan Gerakan Padri. Gerakan ini tujuan awalnya memberantas kebiasaan masyarakat yang dianggap bertentangan dengan agama seperti berjudi, sabung ayam, menggunakan candu dan minum-minuman keras. Akan tetapi gerakan ini mendapat perlawanan dari para penghulu yang tetap mempertahankan adat. Para penghulu yang anti Padri 
kemudian meminta bantuan kepada pihak Belanda dan meletuslah perang Padri pada tahun 1821-1832 (M.C. Ricklefs, 2008: 215). Selain itu ada peristiwa yang terjadi di Yogyakarta yaitu perang Diponegoro (1825-1830) yang dipimpin oleh Pangeran Diponegoro. Meski pun ia belum pernah menunaikan ibadah haji, namun ia mendapat pengetahuan agama dari ulama atau kyai yang pernah melaksanakan haji. Pangeran Diponegoro yang merasa kecewa karena haknya untuk menjadi sultan Yogyakarta telah dirampas, melakukan perlawanan terhadap penguasa Yogyakarta yang bertindak tidak adil dengan berencana membuat jalan menerobos tanah miliknya dan makam yang berada di bawahnya. Ia mendapat bantuan dari kalangan santri yaitu Kyai Madja dan menyatakan perlawananannya itu sebagai perang suci melawan pihak kafir. Mereka memandang bahwa penguasa Yogyakarta telah melakukan penyimpangan agama, termasuk bekerja sama dengan Belanda yang mereka anggap kafir itu.

Para ulama Aceh yang lama tinggal di Mekah dan kembali ke Aceh juga mengambil bagian pada perang Aceh (1873-1912). Para ulama ini terlibat dalam perang ini sebagai bagian dalam menentang agresi Belanda. Selain itu karena agresi ini dilakukan oleh Belanda yang kafir dan pantas dijawab dengan perang atas nama agama. Ada juga pemberontakan yang dilakukan di Cilegon pada 1888. Peranan para haji dalam pemberontakan ini sangat menonjol. Para haji tercatat sebagai pemimpin yang merencanakan dan mematangkan situasi, seperti Haji Abdul Karim, Haji Marjuki, Haji Tubagus Ismail dan Haji Wasid. Dua ulama yang disebutkan merupakan pemimpin langsung pemberontakan. Pemimpin pasukan pada umumnya dan sebagian anak buah mereka terdiri dari para haji.

Seorang haji yang telah kembali dari Mekah ke Tanah Air akan berusaha agar anggota keluarga yang lain dan keluarganya sendiri bisa melaksanakan haji pada masa yang akan datang. Oleh karena itu, usaha mereka tidak berhenti sampai di sini. Mereka berusaha mendapatkan pekerjaan yang menghasilkan banyak uang dan menggunakannya dengan hemat sehingga ia bisa menabung. Banyak dari calon haji yang pada awalnya jarang untuk menabung, kemudian mereka menyisihkan sebagian uangnya sedikit demi sedikit hingga perjalanan yang sudah lama mereka idamidamkan dan yang akan memberikan tempat di mata masyarakat untuk selama sisa hidupnya bisa tercapai (Snouck Hurgronje, 1993: 111). Dari hasil usaha kegiatan perekonomian yang sebenarnya belum memuaskan tersebut, mereka akan menabung sampai beberapa tahun untuk biaya mereka naik haji. Pada akhirnya mereka menjadi sebuah golongan baru dan terjadi perubahan struktur ekonomi dalam masyarakat desa. Haji telah menciptakan sebuah etos bagi umat Islam yaitu kerja keras dan hemat, 
perubahan budaya ekonomi dari jasa ke uang, menciptakan lapangan pekerjaan serta pengenalan transaksi ekonomi antardaerah. Dalam hal keagamaan mereka juga mengembangkan usahanya dengan mengajar di madrasah-madrasah keagamaan yang juga merupakan sumber penghasilan penting (Sartono Kartodirjo, 1984: 85-86).

Sebagian dari jamaah haji yang sudah selesai melaksanakan haji, banyak dari mereka yang menetap di Mekah selama beberapa tahun lamanya untuk menuntut ilmu dan mereka disebut sebagai muqimin. Para muqimin ini oleh penduduk setempat disebut Jawah atau Jawi (orang Jawa) yang bentuk jamaknya Jawwiyin (orang-orang Jawa). Jumlah mereka semakin banyak dikarenakan setiap musim haji banyak jamaah yang menetap di Makkah. Pada awal abad ke XX, telah terjadi perubahan signifikan dalam sistem pendidikan agama di Hindia Belanda. Perubahan ini dipengaruhi oleh sistem pendidikan seperti di Mesir dan Hijaz yang diperkenalkan oleh sebagian haji yang telah pulang ke Tanah Air setelah menyeleseikan pendidikan. Para haji ini memainkan peranan yang cukup penting dalam menyebarkan pendidikan keagamaan di Hindia Belanda.

Di Padang Panjang, Sumatra Barat, pada 1907 didirikan sebuah sekolah yang bernama Adabiyah School/ Madrasah Adabiyah (sekolah peradaban). Sekolah ini didirikan oleh Haji Abdullah Ahmad, seorang pedagang tekstil yang pernah tinggal di Mekah selama empat tahun (1895-1999) (Deliar Noer, 1982: 46). Madrasah ini didirikan atas usul dari teman studi Haji Abdullah Ahmad di Kairo dan Mekah yaitu Thaher Jallaludin yang bertemu dengan nya di Singapura tahun 1906. Madrasah ini bertujuan untuk mencetak generasi muslim yang terpelajar, tidak bertaqlid dan bid'ah serta berijtihad berdasarkan Al-Quran dan hadist.

Selain itu di Padang juga terdapat Surau Jembatan Besi, yaitu sekolah yang memberikan pelajaran agama dengan cara-cara tradisional. Fiqh dan tafsir Quran merupakan pelajaran utama di sekolah ini. Ketika Haji Rasul (Syaikh Abdul Karim Amrullah) dan Haji Abdullah Ahmad masuk ke sekolah ini pada 1904, pelajaran yang ditekankan adalah pelajaran ilmu alat berupa kemampuan untuk menguasai bahasa Arab dan cabang-cabangnya. Haji Rasul pernah tinggal dan melakukan studi di Mekkah selama beberapa tahun sebelum ia mengajar di Surau Jembatan Besi.

Elite agama abad XIX belum sepenuhnya menggunakan Islam sebagai ideologi politik untuk mencapai tujuan dan menata kekuasaan politik. Mereka masih memandang pemerintah kolonial dengan pendekatan tekstual syariah atau fiqh dan aqidah atau tauhid. Akan tetapi pandangan dan sikap politik elit agama yang pernah berhaji ke Makkah pada paroh pertama abad XX berbeda dengan 
ulama abad sebelumnya. Mereka lebih menekankan pada pendekatan kontekstual. Sejalan dengan itu, di kalangan masyarakat muslim mulai timbul gerakan-gerakan pembaharuan yang bertu juan mempersatukan kekuatan muslim untuk melawan hegemoni dari kolonialisme pemerintah Belanda.

Berbagai gerakan pembaharuan banyak dimotori oleh para ulama haji yang telah pulang ke tanah air. Gerakan pembaharuan yang dimunculkan oleh sebagian ulama haji ini melahirkan hubungan kuat antara haji dengan organisasi politik Islam. Organisasi politik Islam merupakan kelompok yang bergerak atau berkepentingan serta terlibat dalam proses politik dan secara aktif berperan dalam menentukan nasib bangsa tersebut berdasarkan nilai-nilai Islam. Sebuah organisasi terbentuk karena di pengaruhi oleh beberapa aspek seperti penyatuan visi dan misi serta tujuan yang sama dengan perwujudan eksistensi sekelompok orang tersebut terhadap masyarakat. Gerakan-gerakan ini mempunyai misi untuk mengubah suatu pola pemikiran menjadi sebuah tindakan. Beberapa bentuk gerakan tersebut adalah PSII dan Permi.

PSII pada awal mulanya berupa organisasi yang bernama Sarekat Dagang Islam (SDI) yang merupakan perkumpulan pedagang-pedagang Islam. Organisasi ini dirintis oleh Haji Samanhoedi di Surakarta pada tahun 1905, dengan tujuan awal untuk menghimpun para pedagang pribumi Muslim (khususnya pedagang batik) agar dapat bersaing dengan pedagang-pedagang besar Tionghoa. SDI merupakan organisasi ekonomi yang berdasarkan pada agama Islam dan perekonomian rakyat sebagai dasar penggeraknya. Di bawah pimpinan H. Samanhoedi, perkumpulan ini berkembang pesat hingga menjadi perkumpulan yang berpengaruh.

Di Surabaya H.O.S. Tjokroaminoto mendirikan organisasi serupa tahun 1912. Ia bergabung dengan SDI pada bulan Mei 1912 atas ajakan dari Haji Samanhoedi, kemudian Tjokroaminoto dipilih menjadi pemimpin SDI (Deliar Noer, 1982: 118). Pada tahun 1912, oleh pimpinannya yang baru Haji Oemar Said Tjokroaminoto, nama SDI diubah menjadi Sarekat Islam (SI). SI ini identik dengan semangat radikalisme pribumi (Khamami zada, 2002: 87). Hal ini dilakukan agar organisasi tidak hanya bergerak dalam bidang ekonomi, tapi juga dalam bidang lain seperti politik.

Sarekat Islam tidak bisa dipisahkan dari peran ulama haji seperti Haji Samanhoedi. Ia lahir di desa Sondokrono sebagai seorang anak pedagang batik yang bernama Haji Moehammad Zen. Setelah ia menyelesaikan pendidikan rendahnya di sekolah kelas dua, Samanhoedi membantu ayahnya dalam berdagang batik. Pada tahun 1904 ia pergi ke Mekah untuk menunaikan ibadah haji dan kembali pada tahun berikutnya (Deliar Noer, 1982: 120). Sekembali dari 
menunaikan ibadah haji, Samanhoedi mempunyai minat yang besar untuk mendirikan sebuah organisasi yang bersifat sosial seperti halnya organisasi yang memberikan bantuan dalam upacara perkawinan maupun keperluan penyelenggaraan kematian. Walaupun pengetahuannya tentang Islam terbatas, ia seorang yang beriman. Dapat dikatakan bahwa ia adalah seorang muslim yang tipikal pada masanya. Bagi Samanhoedi, Islam lah yang membedakan dirinya dari orang asing maupun orang yang nonmuslim.

Adapun tokoh SI lainnya yang cukup berpengaruh adalah H.O.S Tjokroaminoto, seorang lulusan OSVIA atau yang lazim disebut sekolah administrasi pemerintah Belanda. Meski ia lulusan OSVIA, ia tidak pernah menjadi pegawai pemerintah karena lebih tertarik pada dunia politik. Sebelum bergabung dengan SDI, Tjokroaminoto terkenal dengan kejujuran dan keberaniannya menentang kaum bangsawan feodal. Pada 1926, ia berangkat ke Mekah sebagai wakil dari SI dan pemimpin delegasi umat Islam Indonesia pada Kongres Al-Islam pertama yang diadakan oleh Ibn Saud. Kesempatan itu digunakan untuk menunaikan ibadah haji. Kongres itu semula akan membicarakan mengenai masalah pembubaran khalifah oleh Mustafa Kemal, namun karena perkembangan politik di Timur Tengah sedang mengalami peningkatan maka masalah tersebut tidak menjadi agenda pem bicaraan di kongres tersebut.

Pengalaman Tjokroaminoto berinteraksi dengan orang-orang yang berasal dari berbagai belahan dunia telah memengaruhi visi Islam politiknya. Terlebih lagi kegiatan Pan-Islamisme di Timur-Tengah masih hangat diperbincangkan. Setelah selesai melaksanakan kongres, ia kemudian kembali ke Indonesia. Selama kepemimpinannya SI relatif moderat (Deliar Noer, 2001: 286). Di dalam Sarekat Islam, Tjokroaminoto juga dibantu oleh Haji Agus Salim dalam memperjuangkan keberadaan Sarekat Islam. Pengalaman ketika bekerja di Jeddah telah mewarnai pemikiran politiknya di Sarekat Islam. Pada waktu itu, Pan-Islamisme sedang menjadi ideologi yang begitu diminati di dunia Islam. Di waktu yang sama juga mulai berhembus arus modernisme dari Mesir dan gerakan puritanitas yang dipelopori oleh Ibn Abdul Wahab di Hijaz. Agus Salim menjadikan Pan-Islamisme dan modernisme sebagai basis utama untuk aktivitas politiknya.

Gerakan Sarekat Islam pada awalnya lebih merupakan gerakan reaktif terhadap situasi kolonial. Pada tahap-tahap berikutnya gerakan itu melangkah ke arah rekonstruksi kehidupan bangsa, untuk selanjutnya menentukan identitasnya dan akhirnya beralih ke perjuangan politik untuk menentukan nasib sendiri. Di belakang semuanya itu, ternyata ideologi agama mampu memobilisasi massa 
secara besar-besaran. Pada awal abad 20, berbagai ancaman terhadap tatanan kolonial tampak terlihat dari Pan Islamisme dan fanatisme agama. Snouck Hurgronje, menekankan bahwa musuh bukanlah Islam sebagai agama, melainkan Islam sebagai doktrin politik, baik dalam bentuk agitasu nelalui fanatik lokal, maupun dalam bentuk Pan Islamisme.

Banyak ketimpangan yang terkandung dalam hubungan sosial dalam masyarakat kolonial dan mulai dirasakan sebagai hal yang tidak wajar. Namun hal yang lebih menyinggung rasa harga diri mereka adalah hal-hal seperti cara memberi hormat; melakukan sembah, duduk bersila di lantai bagi pribumi, sedangkan untuk keturunan Arab maupun Cina duduk di kursi. Di samping itu berbagai diskriminasi juga membangkitkan rasa inferior, seperti kereta khusus pribumi, pakaian, kamar tunggu stasiun, dan lain sebagainya (Sartono Kartodirjo, 1992: 108). Adapun Permi yaitu sebuah organisasi yang didirikan pada tahun 1930. Permi merupakan kelanjutan dari organisasi Sumatera Thawalib yang berada di Minangkabau dan bergerak dalam bidang pendidikan. Sumatera Thawalib sendiri merupakan penerus dari sekolah agama tradisional yaitu Surau Djembatan Besi yang dahulu didirikan pada peralihan abad ke XX oleh Haji Abdullah Ahmad, yang kemudian dilanjutkan oleh Syekh Daud Rasyidi. Pada tahun 1906, Surau Djembatan Besi diasuh oleh Haji Rasul (Syekh Abdul Karim Amrullah), sekembalinya dari Timur-Tengah. Ketika komunis memperluas pengaruhnya di Minangkabau, beberapa orang ulama haji tertarik dengan ideologi kiri. Mereka terpengaruh konsep komunisme Islam yang ditawarkan oleh Haji Misbah dari Surakarta. Komunis di Minangkabau diperkenalkan oleh Haji Datuk Batuah pada tahun 1923.

Pada tahun 1927 sebagai akibat pemberontakan Silungkang, banyak guruguru Thawalib Padang Panjang dilarang mengajar (Deliar Noer, 1982: 57). Akibatnya sekolah Sumatera Thawalib mengalami kemunduran. Melihat kondisi tersebut, para tokoh Islam berfikir mencari solusi dari masalah tersebut. Tujuannya yaitu para anggota tersebut akan ditempatkan ke dalam sebuah wadah baru yang berupa organisasi politik yakni Persatuan Sumatera Thawalib.

Persatuan Sumatera Thawalib ini terbentuk pada bulan November 1928 M dalam sebuah kongres yang dihadiri oleh utusan-utusan seluruh Sumatera Thawalib. Tujuan organisasi ini untuk mengorganisir kegiatan dalam bidang politik, ekonomi, dan sosial. Pada kongresnya yang ketiga di bulan Mei 1930, Persatuan Sumatera Thawalib mengubah dirinya menjadi Persatuan Muslimin Indonesia (PMI atau Permi), (Audre Kahin, 2005: 58-62). Suatu organisasi kemasyarakatan berasaskan Islam dan Kebangsaan, yang kemudian menjelma menjadi partai politik Islam yang radikal. Anggota organisasi ini terdiri dari para 
bekas pelajar dan guru-guru Sumatera Thawalib yang sejak lama menentang ideologi komunis.

Persatuan Muslimin Indonesia (Permi) dalam waktu dua tahun setelah berdirinya yaitu tahun 1930, berubah menjadi partai politik yang terkuat dan paling berpengaruh di Sumatera Barat. Salah satu penyebab perubahan menjadi partai politik ini adalah karena tidak adanya saluran politik sebagai akibat tertutupnya Muhammadiyah bagi kegiatan politik. Perubahan Permi menjadi partai politik dan menggunakan asas yang berbeda dengan asas organisasi Islam yang lain pada saat itu, yaitu Islam dan Kebangsaan, merupakan salah satu indikasi adanya peningkatan dalam bidang gerakan politik di Minangkabau untuk melawan hegemoni Belanda. Permi semakin kuat dengan pulangnya dua orang ulama haji Minangkabau yang mendapat pendidikan di Mesir yaitu Ilyas Yakub dan Mukhtar Lutfi (Deliar Noer, 1982: 170).

Ilyas Yakub merupakan seorang ulama haji yang mempunyai andil besar dalam melawan hegemoni Belanda di Sumatera Barat. Ia lahir tahun 1903 di Asam Kumbang (Painan) sebagai seorang anak pedagang tekstil (Deliar Noer, 1982: 171). Pada tahun 1921, Ilyas Yakub berangkat bersama gurunya yaitu Syekh H. Abdul Wahab menuju Mekah untuk menunaikan ibadah haji. Seusai melaksanakan ibadah haji ia masih tinggal di sana selama dua tahun untuk memperdalam ilmu agamanya. Selanjutnya ia meneruskan studinya ke Al-Azhar, Mesir, tetapi tidak sebagai mahasiswa penuh (Deliar Noer, 1982: 170).Ia juga pernah menerbitkan sebuah majalah Medan Ra'jat yang berisi tentang perlawanan terhadap Belanda. Ia bersama Mukhtar Lutfi berjuang memimpin Permi melawan penindasan pemerintah Belanda.

Pengaruh haji pada awal abad ke XX telah memunculkan sikap dan pemikiran politik yang lama-kelamaan menjadi sebuah organisasi politik. Orang Islam yang setelah haji belajar di Kairo, mereka membawa berbagai pemikiran politik yang didapatkan dari studi di Mesir itu ke Tanah Air. Dalam perlawanannya kepada pemerintah Belanda mereka memobilisasi masa serta menggunakan simbol-simbol keagamaan.

Awal mula kemunculan organisasi politik Islam yang kemudian bertransformasi menjadi sebuah partai politik Islam memang tidak bisa di lepaskan dari peran haji yang pada waktu itu membentuk berbagai organisasi yang bergerak di bidang ekonomi dan pendidikan. Sarekat Islam (SI) kemudian berubah menjadi PSII, pada awalnya berkembang dari sebuah organisasi yang bernama SDI (Sarekat Dagang Islam). Sebagian haji juga bergerak dalam organisasi pendidikan, seperti organisasi Sumatra Thawalib yang kemudian bertransformasi menjadi Permi (Persatuan Muslim Indonesia). Permi merupakan 
pelopor perjuangan politik yang mengedepankan pemikiran intelektual yang bergerak melalui pendidikan.

Penelitian lain yang menunjukkan peran haji terhadap pemikiran Islam di Indonesia dapat dilihat dalam tulisan Ayumadi Azra yang berjudul Jarigan Ulama Timur Tengah dan Kepulauan Nusantara Abad XVII dan XVIII (Azyumardi Azra, 1998: 291 - 292). Dalam tulisan tersebut menjelaskan bahwa terjadi pembaruan Islam di Minangkabau. Pembaruan Islam yang terjadi di minangkabau tidak hanya berkaitan dengan tarekat syathariyyah yang bukanlah satu-satunya tarekat sufi di Minangkabau. Tarekat Nagsabandiyyah diperkenalkan ke wilayah ini pada paruh abad ketujuh belas oleh Jamal al-Din, seorang Minangkabau yang mula-mula belajar di Pasai sebelum dia melanjutkan ke Bayt Al-Faqih, Aden, Haramayn, Mesir, dan India.

Dalam perjalanan pulangnya, dia berhenti di Aceh sebelum akhirnya sampai ke tanah kelahirannya di Sumatera Barat, di mana dia aktif mengajar dan menyebarkan tarekat naqsabandiyyah. Perjalanan yang dilakukan Jamal al-Din mengingatkan pada pengembaraan Al-Sinkili sebelumnya. Meski Jamal al-Din memberikan riwayat mengenai perjalanannya ke berbagai tempat, tidak seperti Al-Sinkili, dia tidak menyebutkan guru-gurunya sehingga tidak dapat dilacak hubungan dan koneksi ulamaannya. Jamal al-Din adalah penulis teks fiqh Naqsyabandi berjudul Lubab Al-Hidayah yang didasarkan atas ajaran-ajaran Ahmad Ibnu 'Alan Al-Shiddiqi Al-Naqshabandi. Menjelang akhir abad ke delapan belas, tarekat Naqsyabandiyyah dan Qadiriyyah telah melakukan terobosan penting ke Minangkabau. Kedua tarekat ini, sebagaimana tarekat syathariyyah memberikan sumbangan besar terhadap pembaruan masa itu (Azyumardi Azra, 1998: 291 - 292).

Pembaruan tarekat syathariyyah, Naqsyabandiyyah, dan Qadiriyyah, yang paling diwakili Tuanku Nan Tuo dan Jalal al-Din menghadapi tantangan kuat dari para penghulu (pemuka adat) serta dari pengikut tasawuf eksesif. Lebih penting lagi, sebagaimana murid-murid Tuanku Nan Tuo menghadapi pembaruannya sebagai pembaruan kecil-kecil belaka. Yang paling menonjol di antara para murid semacam itu adalah Tuanku Nan Renceh yang menghendaki pembaruan lebih menyeluruh dan radikal.

Setelah gagal membujuk Tuanku Nan Tuo untuk mengubah pendekatannya yang evolusioner dan damai terhadap pembaruan Islam, Tuanku Nan Renceh mendapatkan para pendukung kuat dari tiga haji yang kembali dari Makkah pada 1218/1803. Haji Miskin, Haji Sumanik, dan Haji Piobang. Perjalanan ibadah haji mereka bersamaan dengan dikuasainya Makkah oleh kaum Wahabi. Karena itu, cukup beralasan jika dianggap bahwa mereka 
dipengaruhi oleh ajaran-ajaran wahabi, seperti penentangan terhadap bid'ah, penggunaan tembakau dan pemakaian baju sutera, yang mereka sebarkan secara paksa terhadap masyarakat di wilayah Minangkabau.

Tuanku nan Renceh bersama dengan tiga haji itu yang dikenal dengan sebutan Padri, menyerukan jihad melawan muslim yang tidak mau mengikuti ajaran-ajaran mereka. Akibatnya perang saudara meletus di tengah masyarakat Minangkabau; surau-surau, yang dianggap sebagai kelompok-kelompok bid'ah diserang dan dibakar hingga rata dengan tanah termasuk surau-surau Tuanku Nan Tuo dan Jalal al-Din. Keluarga bangsawan dan para penghulu yang juga menjadi sasaran utama segera meminta bantuan Belanda. Dengan campur tangan Belanda, perjuangan Minangkabau untuk pembaruan berubah menjadi perang Padri melawan Belanda, dan perang itu baru berakhir pada penghujung tahun 1830-an.

Dari uraian di atas jelas menunjukkan bahwa ada pengaruh jamaah haji terhadap pemikiran keagamaan yang dibawah ketika mereka kembali ke tanah air. Pada saat penjajahan, pemikiran jamaah haji yang kembali ke tanah air menjadi ancaman tersendiri bagi para penjajah Belanda. Pemikiran yang dibawa membawa semangat perjuangan untuk mengusir penjajah Belanda, di samping ada beberapa pemikiran keagamaan yang berbenturan sendiri dengan pemikiran keagamaan lokal yang telah lama berkembang.

Berbeda dengan saat ini di mana pemikiran agama yang radikal cenderung berkembang dan sering berbenturan dengan pemikiran-pemikiran keagamaan yang telah lama berkembang. Mereka dengan mudah membid'ahkan, menyalahkan, bahkan sampai pada titik tertinggi adalah mengkafirkan kelompok lain yang berbeda pemikiran dengannya. Tidak sampai pada pemikiran saja, gerakan politik pun muncul dari golongan ini. Agenda politik yang diinginkan adalah terciptnya khilafah Islamiyah di Indonesia. Indonesia yang berdasar pada Pancasila dan Undang-Undang Dasar Negara Republik Indonesia 1945 ingin dirubah menjadi Negara Islam. Gerakan ini yang membahayakan dan mengancam keutuhan Negara Kesatuan Republik Indonesia. Pemikiran dan gagasan seperti ini tidak lepas dari pemikiran wahabi yang ekstrem yang mengarah pada kekersan. Pemikiran keagamaan yang seperti ini juga sangat mungkin akan mempengaruhi jamaah haji Indonesia.

\section{RADIKALISME: ANCAMAN TERHADAP NEGARA KESATUAN REPUBLIK INDONESIA}

Negara Kesatuan Republik Indonesia (NKRI) dapat terbentuk berkat perjuangan para pendiri bangsa dahulu awal kemerdekaan RI. Mereka berjuang sepenuh hati, mereka korbankan kehidupan mereka untuk bisa mewujudkan 
persatuan dan keutuhan Negara Republik Indonesia. Sehingga sampai sekarang kita kenal banyak pahlawan bangsa yang sudah gugur jauh mendahului kita dalam rangka memperjuangkan cita-cita luhur bangsa.

Sayangnya banyak generasi penerus yang tidak tahu atau tidak mau tahu dengan perjuangan mereka para leluhur pendiri bangsa. Sehingga timbulah sekarang ini banyak kelompok-kelompok yang secara diam-diam atau terangterangan ingin mengganti dasar negara Republik Indonesia yang merupakan landasan terwujudnya persatuan dan kesatuan RI. Di antara kelompokkelompok tersebut adalah mulai dari gerakan moral ideologi seperti Majelis Mujahidin Indonesia dan Hizbut Tahrir Indonesia (HTI) sampai kepada gaya militer seperti Laskar Jihad, dan FPI (Endang Turmudi (ed), 2005:5).

Mereka menyempal dan berafiliasi ke jaringan Islam aliran keras. Mereka yang setuju dengan penggantian Pancasila dan UUD 45 bergabung dan membuat kelompok ekslusif yang dibungkus dengan agama, sehingga terkesan menarik bagi orang-orang awam yang tidak paham dengan politik. Orang awan ini merasa terakomodasi ide-idenya, sebagai orang yang marginal atau termarginalkan, mereka sama-sama tidk puas dengan pengelolaan Negara yang ada sekarang ini.

Sehingga mereka berbondong-bondong bergabung dan mendukung ide penggantian idiologi Pancasila yang sudah menjadi kesepakatan bersama antara rakyat dan pemerintah. Mereka bersatu dan bertekad ingin mengganti idiologi Pancasila dengan sangat halus. Mereka berusaha memiliki sekolah sendiri, bank sendiri,usaha sendiri, jaringan bisnis sendiri dan seterusnya yang semua itu dijalankan oleh kelompok beraliran keras dengan dibungkus agama (https://m.tempo.co/read/news/2015/02). Gerakan radikalisme di Indonesia sampai detik ini tidak lagi hanya sebatas pada tuntutan dipenuhinya aspirasi islam, seperti pemberlakuan syariat islam atau piagam madinah (Azyumardi Azra, 2000: 45), tetapi sudah mengarah pada gerakan politik.

Apabila ada organisasi mengganggu ketertiban umum, memecah belah umat dan NKRI, bertentangan dengan ideologi Pancasila, maka Pemerintah harus campur tangan. Pemerintah untuk tidak sekadar berwacana dalam menangkal perkembangan radikalisme di Indonesia, namun harus berupa tindakan reaktif cepat dan tepat sasaran. Pemerintah agar menegakan undangundang terorisme secara maksimal sehingga terorisme tidak berkembang di Indonesia.

Kompomponen yang berperan penting terhadap situasi suatu negara, yaitu agama, ekonomi dan politik. Faham radikalisme kegiatannya dapat dikategorikan sebagai terorisme dimana terdapat suatu ancaman, kekerasan dan 
mengambil hak asasi manusia. Untuk itu, bangsa Indonesia harus bekerjasama menentang dan melawan untuk meminimalisir dampak dari faham radikalisme serta mendorong pemerintah untuk mencoba mengurai potret kemunculan faham radikalisme dengan mencoba membatasi potensi-potensi perkembangan faham itu dari luar, yakni dengan cara membentengi NKRI dari paham-paham yang tidak dibenarkan oleh agama. Salah satunya bentengi NKRI dengan pemahaman sesuai ajaran Islam melalui pengajian, pendekatan anak dengan orangtua, dan melalui diskusi-diskusi, juga penyuluhan terhadap calon jama'ah haji.

Yang tidak kalah penting adalah revitalisasi lembaga, badan, dan organisasi kemahasiswaan intra maupun ekstra kampus. Organisasi-organisasi yang ada di kampus memegang peranan penting untuk mencegah berkembangnya paham radikalisme ini melalui pemahaman keagamaan dan kebangsaan yang komprehensif dan kaya makna.

Keanggotaan dan aktivisme organisasi merupakan faktor penting untuk mencegah terjerumusnya seseorang ke dalam gerakan radikal yang ekstrem. Sebaliknya terdapat gejala kuat para mahasiswa yang non aktivis dan kutu buku sangat mudah terkesima sehingga segera dapat mengalami cuci otak dan indoktrinasi pemikiran radikal dan ekstrem. Mereka cenderung naif dan polos karena tidak terbiasa berpikir analitis, kritis, seperti lazimnya dalam kehidupan dunia aktivis.

Menggalakkan propaganda anti radikalisme seharusnya menjadi salah satu agenda utama untuk memerangi gerakan radikalisme dari dalam kampus dan komunitas-komunitas lain, termasuk di dalamnya adalaha calon jamaah haji. Peran itu menjadi semakin penting karena organisasi mempunyai banyak jaringan dan pengikut sehingga akan memudahkan propaganda-propaganda kepada kader-kadernya. Jika ini dilaksanakan dengan konsisten, maka pelan tapi pasti gerakan radikalisme bisa dicegah tanpa harus menggunakan tindakan represif yang akan banyak memakan korban dan biaya.

Untuk mengatasi hal ini perlu langkah strategis, inovatif, terpadu, sistematis, serius, dan komprehensif. Yang diperlukan bukan hanya pendekatan keamanan dan ideologi, tetapi juga memperhatikan jaringan, modus operandi, dan raison d'etre gerakan ini. Perlu perpaduan langkah ideologis, program deradikalisasi melalui masyarakat sipil, serta pendekatan ekonomi dan sosial. Ini guna mencegah para mantan aktivis gerakan radikal dan teroris agar tak kembali pada komunitas lamanya. Program "memanusiakan" ini, juga menjadi salah satu prasyarat mencegah meluasnya aksi radikalisme dan terorisme. 


\section{KESIMPULAN}

Pemikiran Islam Indonesia memang tidak lepas dari pemikiran Islam yang berkembang di Timur Tengah. Pemikiran Islam Indonesia mampu melakukan akomodasi dan adaptasi dengan sosio-kultur masyarakat setempat yang sangat heterogen. Dengan kenyataan masyarakat yang sangat heterogen tersebut menjadikan cara berfikir yang saling menghargai dan menghormati menjadi sebuah keharusan.

Islam yang toleran yang sudah berkembang selama ini mengalami gangguan dengan masuknya pemikiran-pemikiran islam baru yang cenderung ekstrem. Radikalisme yang berkembang di Timur Tengah sudah menjangkiti sebagian kelompok muslimIndonesia. Lebih-lebih gerakan yang dilakukan tidak semata-mata dalam tahap pemikiran tetapi sudah pada gerakan politik. Gerakan politik yang diusung adalah keinginan mendirikan khilafah islamiyah seperti yang dilakukan oleh Hizbut Tabrir Indonesia (HTI).

Dengan maraknya radikalisme yang masuk ke Indonesia maka sangat penting untuk melakukan langkah-langkah antisipatif. Berkaitan dengan antusiasme menunaikan ibadah yang sangat tinggi muslim Indonesia, maka perlu menjadi perhatian semua pihak terutama instansi terkait untuk menjaga dan membentengi mereka agar tidak terjerumus dengan bergabung gerakan-gerakan radikalisme tersebut. Maka dari itu, penanaman nilai-nilai wawasan kebangsaan bagi calon jamaah haji mejadi satu keharusan. Di samping calon jamaah haji mendapatkan bimbingan manasik haji, calon jamaah haji juga perlu mendapatkan bimbingan dan pengarahan untuk tidak terpengaruh dengan pemikiran-pemikiran islam yang radikal yang membahayakan keutuhan Negara Kesatuan Republik Indonesia.

Upaya untuk mengantisipasi dan menanggulangi pemikiran Islam yang radikal dapat dilakukan oleh semua pihak. Kementerian Agama dalam hal ini dapat membuat program pembekalan terhadap calon jamaah haji dalam hal penguatan nilai-nilai wawasan kebangsaan. Kementerian Agama juga dapat menginstruksikan kepada seluruh struktur sampai tingkat Kantor Urusan Agama untuk melakukan hal yang sama. Kegiatan yang sama juga dapat dilakukan oleh para pembimbing jamaah haji atau Kelompok Bimbingan Ibadah Haji (KBIH) dan juga organisasi yang terkait dengan haji, misalnya Ikatah Persaudaraan Haji Indonesia (IPHI) dan Angkatan Muda Haji Indonesia (AMHI).] 


\section{DAFTAR PUSTAKA}

Algar, Hamid, Wahhabism: A Critical Essay, terj. Rudy Harisyah Alam, Wahabisme sebuah Tinjauan Kritis, (Jakarta: Demokracy Project, 2011).

Azra, Azyumardi, "Muslimin Indonesia: Viabilitas "Garis Keras" , dalam Gatra edisi khusus 2000.

....., Jarigan Ulama Timur Tengah dan Kepulauan Nusantara Abad XVII dan XVIII, (Bandung: Mizan, 1998, cet. IV).

Boulatta, Issa J., Dekonstruksi Tradisi: Gelegar Pemikiran Arab Islam, (Yogyakarta: LKiS, 2001)

Hurgronje, Snouck Politik Haji, terj. Soedarso Soekarno, Kumpulan Karangan Snouck Hurgronje, (Jakarta: INIS, 1993).

Kahin, Audre Dari Pemberontakan ke Integrasi: Sumatera Barat dan Politik Indonesia 1926-1998 (Jakarta: YOI, 2005).

Kartodirjo, SartonoPemberontakan Petani Banten 1888 (Jakarta: Pustaka Jaya, 1984).

Sejarah Pergerakan Nasional, Dari Kolonialisme Sampai Nasionalisme (Jakarta: Gramedia, 1992).

M.C. Ricklefs, Sejarah Indonesia Modern 1200-2004 (Jakarta: Serambi, 2008).

Noer, Deliar, Membincangkan Tokoh-Tokoh Bangsa (Bandung: Mizan, 2001).

.......,Gerakan Modern Islam di Indonesia 1900-1942 (Jakarta: LP3ES, 1982).

Putuhena, M. Shaleh, Historiografi Haji Indonesia (Yogyakarta: LKiS, 2007).

Turmudi, Endang (ed), Islam dan Radikalisme di Indonesia, (Jakarta :LIPI Press, 2005).

Wahid, Hasyim, dkk, Telikungan Kapitalisme Global, (Yogyakarta: LKiS, 1999).

Yudha, Pengarub Haji terhadap Politik Islam di Indonesia (Tahun 1900 - 1945), Thaqafiyyat, Vol. 16 No. 1, 2015.

Zada, Khamami, Islam Radikalisme, (Jakarta: Teraju, 2002).

https://m.tempo.co/read/news/2015/02/06/058640488/ormas-ini-ditudingmenyimpang-dari-ajaran-islam diakses 04 Oktober 2017 